\title{
Analisis Naratif Pemberitaan Prancis Sebagai Juara Piala Dunia 2018 di Harian Kompas
}

\author{
Hilman Syahrul Yuzi ${ }^{1}$, Subhan Afifi ${ }^{2}$, Yenni Sri Utami ${ }^{3}$ \\ 1,2,3 Jurusan Ilmu Komunikasi, Fakultas Ilmu Sosial dan Politik, \\ Univeritas Pembangunan Nasional "Veteran" Yogyakarta \\ 1,2,3 Jalan Babarsari 2, Tambakbayan, Yogyakarta 55281, Indonesia \\ Email: hilmansyahrulyuzi@gmail.com ${ }^{1}$; subhanafifi@yahoo.com ${ }^{2}$; yenni.sriutami@upnyk.ac.id ${ }^{3}$; \\ *corresponding author
}

\begin{abstract}
The World Cup is held every four years is an attraction for all football lovers around the world. The 2018 World Cup held in Russia holds the title with the most record audience in history with 3.572 billion, despite being hit by various conflicts. This study aims to analyze the narrative character of the French news as the 2018 World Cup winners in the Kompas daily edition of 10-17 July 2018. This research uses qualitative methods, with data collection techniques through Kompas daily written documents of the 10-17 July 2018 edition, as well as conducting interviews on 9, and 16 January 2019, and on 9 March 2019. The theory used to analyze the character of a narrative is a narrative theory, which is the process of conveying and sequencing an event in sequence. The results of this study indicate that the characteristics of the Kompas daily narrative in proclaiming France as the 2018 World Cup champions are descriptive narratives, not sensational narratives. In addition, the Kompas daily does not have a special writing style and refers more to the general narrative for football by using diction that matches the Enhanced Spelling. Kompas daily placed France with strong and compact characteristics so that it was able to win the 2018 World Cup. The contribution of this research was in the form of policy recommendations to other news media in order to write easily understood narrative news with narrative characteristics that are common to readers.
\end{abstract} Keywords: World Cup, France, Kompas Daily, Narrative Character

\begin{abstract}
Abstrak
Piala Dunia digelar empat tahun sekali menjadi daya tarik bagi seluruh pecinta sepakbola di seluruh dunia. Piala Dunia 2018 yang diselenggarakan di Rusia menyandang predikat dengan rekor penonton terbanyak sepanjang sejarah dengan 3,572 miliar, meskipun sempat dilanda berbagai konflik. Penelitian ini bertujuan untuk menganalisis karakter narasi pemberitaan Prancis sebagai juara Piala Dunia 2018 di harian Kompas edisi 10-17 Juli 2018. Penelitian ini menggunakan metode kualitatif, dengan teknik pengumpulan data melalui dokumen tertulis harian Kompas edisi 10-17 Juli 2018, serta melakukan wawancara pada tanggal 9, dan 16 Januari 2019, serta pada tanggal 9 Maret 2019. Teori yang digunakan untuk menganalisis karakter narasi adalah teori naratif, yakni proses menyampaikan dan merangkai suatu peristiwa secara berurutan. Hasil penelitian ini menunjukkan bahwa karakteristik narasi harian Kompas dalam memberitakan Prancis sebagai juara Piala Dunia 2018 adalah narasi deskriptif, bukan narasi sensasi. Selain itu, harian Kompas tidak memiliki gaya tulisan yang spesial dan lebih mengacu pada narasi umum untuk sepakbola dengan menggunakan diksi yang sesuai Ejaan Yang Disempurnakan. Harian Kompas menempatkan Prancis dengan karakteristik yang kuat dan kompak sehingga mampu keluar sebagai juara Piala Dunia 2018. Kontribusi penelitian ini berupa rekomendasi kebijakan kepada media pemberitaan lain agar menuliskan berita narasi yang mudah dipahami dengan karakteristik narasi yang umum bagi pembaca. Kata kunci: Piala Dunia, Prancis, Harian Kompas, Karakter Narasi
\end{abstract}

\section{Pendahuluan}

Olahraga sepakbola merupakan sebuah permainan yang dimainkan oleh 11 pemain dengan dua kesebelasan yang saling bertanding di atas rumput hijau. Pemenangnya ditentukan oleh salah satu kesebelasan yang mencetak angka lebih banyak dan dimainkan selama
90 menit, yang terbagi menjadi dua babak. Sepakbola menjadi salah satu olahraga yang paling diminati di seluruh dunia. Hampirseluruh umat diduniamenggandrungi sepakbola yang dalam istilah populernya football. Tanpa memandang usia, kelas sosial, serta jenis kelamin, sepakbola mampu menyedot perhatian 
publik dalam jumlah besar dari lingkungan masyarakat di tingkat lokal sampai internasional. Apalagi saat Piala Dunia 2018 Rusia, sekitar $57 \%$ pembeli tiket berjenis kelamin perempuan yang berasal dari China. Penggemar sepakbola asal China berjumlah 100 ribu orang berangkat ke Rusia menempati peringkat ketiga. Selain itu, terdapat 20 penerbangan yang mengangkut 4.000 orang dari China ke Rusia setiap hari.

Menurut data audiensi liputan siaran resmi Piala Dunia 2018, gabungan 3,572 miliar khalayak mengikuti turnamen akbar empat tahunan tersebut, yang disiarkan secara langsung di setiap wilayah di seluruh dunia. Penonton televisi di rumah setidaknya satu menit liputan berjumlah 3,262 miliar. Ketika laga final mampu menarik khalayak global gabungan 1,12 miliar, terdiri dari 884,37 juta yang menyiarkan liputan televisi linear dan 231,82 juta khalayak di luar rumah. Lebih dari 64 pertandingan, rata-rata penonton yang menyaksikan secara langsung adalah 191 juta.

Pada Piala Dunia 2018 tercatat ada 9 kesempatan di mana sebuah tim mencetak gol kemenangan di atas waktu normal 90 menit, atau di masa Injury Time. Jumlah ini merupakan rekor terbanyak dalam sejarah Piala Dunia, mengalahkan rekor sebelumnya yang terjadi pada Piala Dunia 2014 Brazil dengan 4 kesempatan. Selain itu, persentase gol melalui set piece, atau tendangan bola mati merupakan yang terbanyak sepanjang masa. Tercatat sejumlah 43\% gol di Piala Dunia 2018 berawal dari set piece dan rata-rata usia pemain yang berlaga di Piala Dunia 2018 mencapai 28 tahun.

Prancis berhasil meraih gelar juara Piala Dunia untuk kali kedua, yang sebelumnya diraih pada Piala Dunia 1998 saat menjadi tuan rumah. Di laga final, Prancis sukses menaklukan Kroasia dengan skor 4-2. Selain itu, sang pelatih, Didier Deschamps menjadi orang ketiga yang berhasil menjadi juara dunia sebagai pemain dan pelatih. Sebelumnya diraih oleh Mario Zagallo dan Franz Beckenbauer.
Harian Kompas mengirimkan para jurnalisnya ke Rusia untuk meliput sepanjang gelaran Piala Dunia 2018. Harian Kompas dalam hal memberitakan Piala Dunia 2018, tidak hanya terkait pada setiap pertandingan yang akan dan telah berlangsung, namun dari sisi luar sepakbola dan historis pun turut diberitakan.

Berita Prancis juara Piala Dunia 2018 Rusia digambarkan oleh harian Kompas dengan gaya bahasa lugas, hemat kata, dan sederhana. Hal ini lantaran agar orang awam dapat mudah memahami setiap kalimat pada berita seputar Piala Dunia. Selain itu, lantaran harian Kompas memberitakan langsung di Rusia saat gelaran Piala Dunia, segmentasi tentang Piala Dunia 2018 dikemas secara menarik, sehingga peneliti lebih memilih harian Kompas untuk dijadikan bahan penelitian daripada harian Jawa Pos. Hal ini karena peneliti membandingkan kedua media cetak tersebut dalam memberitakan seputar Piala Dunia 2018. Peneliti menilai harian Kompas lebih rinci, komplit, dan mengulik sisi lain dalam memberitakannya secara menyeluruh sehingga pembaca dapat memahami lebih jauh tentang Piala Dunia 2018.

Penelitian lain yang dilakukan oleh Rangga L. Tobing, mahasiswa Universitas Pendidikan Indonesia yang berjudul Struktur Narasi Wacana Olahraga Sepakbola Pada Media Massa Daring di Indonesia, dengan menggunakan teknik analisis naratif. Objek dari penelitian ini adalah berupa artikel di portal berita online Suara. com, Detik.com, Goal.com, Republika.co.id, Jawapos.com, Tempo.co, dan Kompas.com mengenai kemenangan Real Madrid menjuarai Liga Champions Eropa tahun 2014. Kesimpulan penelitian tersebut adalah Real Madrid lebih banyak ditempatkan sebagai subjek utama dalam setiap adegan, sementara Atletico Madrid lebih berperan sebagai penghalang subjek. Penelitian ini dengan penelitian sebelumnya memiliki kesamaan terkait metode penelitian serta topik sepakbola yang dibahas. Perbedaan penelitian ini dengan sebelumnya terdapat 
pada objek penelitian dan kompetisi sepakbola.

Penelitian sebelumnya hanya mengambil berita ketika di partai final dari beberapa media daring, tanpa melihat pemberitaan yang lebih dalamdiantarakeduatimsebelumbertemudifinal. Hal ini yang menjadi kekurangan rangkaian cerita untuk menganalisa dan meneliti topik penelitian secara terperinci, sehingga tujuan penelitian untuk menganalisis karakter narasi pemberitaan Prancis sebagai pemenang Piala Dunia 2018 Rusia di harian Kompas edisi 10-17 Juli 2018.

\section{Teori Naratif}

Teori naratif adalah salah satu teori modern yang dikembangkan dari teori klasik oleh beberapa ahli di dunia. Teori yang berlandas terhadap sturkturalisme ini menekankan pada proses naratologi pada sebuah cerita atau teks dan pemaknaannya. Beberapa tokoh mengkaji terbentuknya teori naratif, antara lain Vladimir Propp, AJ Greimas, Seymour Chatman, dan Tzvetan Todorov (Siswanto, 2008).

Naratif juga berasal dari kata narasi yaitu suatu cerita tentang peristiwa atau kejadian dengan adanya paragraf narasi yang disusun dengan merangkai peristiwa-peristiwa yang berurutan atau secara kronologis. Tujuannya, pembaca diharapkan seolaholah mengalami sendiri peristiwa yang diceritakan. Dengan mengalami sendiri dan masuk ke dalam sebuah cerita, pembaca memiliki kesempatan untuk mengasumsikan dan menciptakan sendiri imajinasi mereka mengenai kebenaran dalam teks tersebut.

Argirdas Greimas menganalogikan bahwa narasi sebagai suatu struktur makna (semantic structure). Setiap kata dalam kalimat menempati posisi dan fungsinya masing-masing sehingga membentuk kesatuan yang koheren dan mempunyai makna. Greimas juga melihat narasi sebagai sebuah semantik dalam kalimat, di mana dalam narasi tersebut terdapat relasi dari masing-masing karakter (Eriyanto, 2013: 95).

Dalam Eriyanto (2013: 96) karakter narasi dalam model Greimas lebih ditekankan adalah objek atau aktivitas dari karakter dalam berita. Ketika menganalisis teks berita, harus menentukan objek yang diberitakan. Setelah itu menentukan peran dalam karakter narasi model Aktan berupa subjek, objek, pendukung, pengirim, penerima, dan penghambat.

\section{Surat Kabar dan Pemberitaan}

Berita adalah laporan atau pemberitahuan tentang segala peristiwa aktual yang menarik perhatian orang banyak. Pengertian berita lainnya adalah informasi yang layak disajikan kepada publik. Berita yang tergolong layak adalah informasi yang sifatnya faktual, aktual, akurat, objektif, penting, dan menarik perhatian publik. Surat kabar adalah media komunikasi yang berisikan informasi aktual dari berbagai aspek kehidupan, seperti politik, ekonomi, sosial, kriminal, budaya, seni, olahraga, dan sebagainya (Suryawati, 2014: 40). Surat kabar menampung seluruh keperluan masyarakat terhadap informasi dan terbit untuk mewadahi kebutuhan masyarakat sehari-hari. Kelebihan surat kabar adalah sebagai catatan tertulis yang mampu merekam peristiwa atau kejadian di masa lampau, meskipun peristiwa tersebut sudah terjadi beberapa puluhan tahun yang lalu (Tamburaka, 2013: 45-46). Selain itu, kelebihan surat kabar lainnya adalah mampu menyajikan informasi atau berita secara komprehensif, dapat dibawa ke mana-mana, dapat didokumentasikan, dapat dibaca berulang-ulang, serta mudah diperoleh jika diperlukan (Suryawati, 2014: 41).

\section{Analisis Naratif}

Analisis menempatkan berita tidak ubahnya seperti sebuah novel, puisi, cerpen, atau cerita rakyat. Analisis naratif adalah analisis mengenai narasi, baik narasi fiksi (novel, puisi, cerita rakyat, dongeng, film, komik, musik dan sebagainya) ataupun fakta seperti berita. Menggunakan analisis naratif berarti menempatkan teks sebagai sebuah cerita (narasi) sesuai dengan karakteristik di atas. Teks dilihat sebagai rangkaian peristiwa, logika, dan tata urutan peristiwa, bagian dari peristiwa yang dipilih dan dibuang (Eriyanto, 2013: 9). 
Jane Stokes menyatakan bahwa analisis naratif menggunakan keseluruhan teks sebagai objek analisis (Stoke, 2007: 72). Analisis naratif memiliki beberapa kelebihan, diantaranya: 1) Analisis naratif membantu kita untuk memahami bagaimana makna, pengetahuan, dan nilai di produksi kemudian disebarkan pada masyarakat; 2) Memungkinkan kita untuk menyelidiki hal-hal tersembunyi dari suatu teks media; dan 3) Merefleksikan kontinuitas dan perubahan komunikasi. Jurnalisme Olahraga

Jurnalisme olahraga menggunakan eksplorasi dan pendekatan induktif untuk menganalisis artikel secara tekstual sebagai narasi media yang sebagian besar seragam muncul. Penulis olahraga memainkan kunci dalam membantu dan membangun keberhasilan dan pemulihan metaforis dan sarana kolektif. Dengan demikian, superdome sebagai ruang memori kolektif harus dipertimbangkan dalam batas-batas jurnalisme olahraga. Sebagai narasi memori kolektif, penulis olahraga memposisikan sebagai tempat pemulihan kisah-kisah yang diceritakan kembali tentang ruang menghidupkan pemahaman. Jurnalisme olahraga memiliki lisensi untuk terlibat dalam menghibur audiens, karena melaporkan berita sebagai objek hiburan (Serazio, 2010: 156-160). Jurnalis olahraga juga harus berkomitmen pada generasi konten berkualitas tinggi dan mengejar keunggulan di bidang jurnalisme olahraga. Hal ini mengingat pertimbangan dalam literatur ekstensif serangkaian masalah standar normatif, dan kriteria konvensional profesi. Jurnalis olahraga harus mendapatkan kesadaran akuntabilitas mereka dan mengasumsikan bahwa jurnalisme olahraga tidak boleh dikecualikan dari pengamatan mengenai kriteria konvensional dalam berita (Vegas and Torrijos, 2017: 160).

\section{Piala Dunia}

Piala Dunia sebagai ajang empat tahunan sanggup menghipnotis para penonton yang terpisahkan oleh jarak dan kewarganegaraan. Event yang paling ditunggu penduduk muka bumi ini telah bermetamorfosis menjadi arena pertunjukan, bukan sekedar pertandingan memperebutkan gol di atas lapangan hijau. Tak dapat disangkal lagi jika Piala Dunia telah melahirkan demam kegilaan atas sepakbola di kasta tertinggi (Junaedi, 2014: 87).

Selain itu, Piala Dunia tetap menyimpan daya magis yang takkan pernah lekang oleh zaman. Dalam turnamen inilah, sepakbola menjadi sebuah permainan prestisius yang tela menyedot perhatian puluhan milyar pemirsa televisi di seluruh dunia dan menjadi lading bisnis terbesar dalam dunia olahraga. Sementara bagi seluruh pemain yang berlaga, turnamen ini menjadi ajang unjuk gigi, gengsi, ambisi, dan pembuktian diri untuk menjadi tim sepakbola terbaik yang ada di jagat raya dengan meraih gelar juara (Sukendro, 2014: 7-9).

\section{Metode Penelitian}

Penelitian yang digunakan pada penelitian ini adalah penelitian kualitatif. Penelitian kualitatif didasarkan pada upaya membangun pandangan mereka yang diteliti rinci, dibentuk dengan katakata, gambar holistik, dan rumit (Sugiyono, 2016; Sutopo, 2002). Penelitian ini tidak menggunakan prosedur analisis statistik atau cara kuantifikasi lainnya (Moleong, 2010: 6). Penelitian ini bersifat interpretif dengan menggunakan paradigma konstruktivisme. Paradigma konstruktivisme menganggap realitas sosial dilihat sebagai hasil konstruksi sosial sehingga kebenaran suatu realitas sosial bersifat relatif. Media menyusun realitas dari berbagai peristiwa yang terjadi hingga menjadi cerita yang bermakna. Dalam proses konstruksi realitas, bahasa merupakan instrumnen pokok untuk menceritakan realitas, dengan arti bahasa sebagai alat konseptualisasi 
dan alat narasi (Sobur, 2013: 74-75).

Teknik pengumpulan data dalam penelitian kualitatif ini menggunakan data primer berupa dokumen tertulis berita seri Harian Kompas pada edisi 10-17 Juli 2018 yang berkaitan dengan negara Perancis yang menjadi juara Piala Dunia 2018 Rusia. Selain itu, beberapa data sekunder sebagai pelengkap seperti informasi yang berkaitan di media massa lain dan dengan mempelajari buku-buku atau literatur yang terkait dengan permasalahan yang diteliti.

Penelitian ini menggunakan teknik analisis data model Miles and Huberman. Analisis data pada model ini dilakukan pada saat pengumpulan data berlangsung, dan setelah selesai pengumpulan data dalam periode tertentu. Terdapat tiga komponen utama dalam analisis data, yaitu redaksi data, sajian data, dan penarikan kesimpulan. Penelitian ini menggunakan analisis naratif. Peneliti melakukan identifikasi karakteristik teks media cetak menggunakan analisis naratif sebagai teori dan metode penelitian dengan model Algirdas Greimas.

\section{Hasil Penelitian dan Pembahasan}

Berdasarkan temuan hasil penelitian, terdapat delapan berita terkait Prancis sebagai juara Piala Dunia2018, terhitungsejakbabaksemifinal,yaitu:

\section{Berita Adu Taktik Di Jumpa Pertama}

Berita ini menceritakan laga semi final antara Prancis melawan Belgia. Kedua pelatih akan beradu taktik dan strategi untuk meraih satu tiket ke final. Bagi Didier Deschamps, ia siap melakukan berbagai skenario melawan Belgia. Sedangkan Roberto Martinez, akan memberikan kejutan di laga penting ini.

Dalam berita ini terdapat enam karakteristik narasi, yaitu taktik dan strategi bermain sebagai pengirim, skenario pertandingan sebagai objek, Prancis dan Belgia sebagai penerima, pemain menjalankan taktik sebagai pendukung, Didier Deschamps \& Roberto Martinez sebagai subjek, dan Belgia lawan yang tangguh sebagai penghambat. Harian Kompas menempatkan Belgia sebagai penghambat karena siap menghentikan taktik dan strategi Prancis untuk merusak skenario pertandingan yang telah dirancang untuk melaju ke final.

\section{Berita Ancaman Taji Si 'Ayam Jantan'}

Berita ini berisi tentang ketajaman Prancis, baik lini belakang maupun lini depan, yang diibaratkan layaknya Ayam Jantan. Hal ini ditandai dengan gol-gol kemenangan Prancis melawan Argentina, Uruguay, serta Belgia lewat para pemain belakangnya sehingga mengantarkan Prancis melaju ke final.

Dalam berita ini terdapat enam karakteristik narasi, yaitu keberadaan pemain belakang sebagai pengirim, ketajaman timnas Prancis sebagai objek, melaju ke final Piala Dunia 2018 sebagai penerima, kemampuan menyerang dengan baik sebagai pendukung, simbol Ayam Jantan sebagai subjek, dan Kroasia bermain efektif sebagai penghambat. Harian Kompas menempatkan Kroasia sebagai penghambat karena dengan permainan efektif akan menghentikan ketajaman timnas Prancis sepanjang turnamen untuk menodai catatan simbol Ayam Jantan yang akan melaju ke final.

\section{Berita Les Bleus Melawan Besar Kepala}

Berita ini menceritakan pentingnya kebersamaan dalam sebuah tim dibandingkan keegoan individual serta rasa besar kepala. Hal ini mengingatkan Prancis ketika kalah di final Piala Eropa 2016 saat bertindak sebagai tuan rumah. Maka, penting bagi mereka untuk menekankan kolektivitas tim daripada aspek individual.

Dalam berita ini terdapat enam karakteristik narasi, yaitu Piala Dunia 1998 sebagai pengirim, kolektivitas dan kebersamaan timnas Prancis sebagai objek, penantian juara Piala Dunia untuk pendukung Prancis sebagai penerima, enggan mengulang kesalahan di final Piala Eropa 2016 sebagai pendukung, Antoine Griezmann sebagai subjek, dan rasa besar kepala serta ego individual sebagai penghambat. Harian Kompas menjadikan ego individu dan rasa besar kepala sebagai 
penghambat Antoine Griezmann dan kawan-kawan sebelum bertanding di final melawan Kroasia. Hal ini lantaran mereka tidak ingin terjadi seperti final Piala Eropa 2016 dan akan bermain sebagai tim yang solid untuk penantian gelar juara Piala Dunia 2018. Berita Semua Untuk Satu, Satu Untuk Trofi

Berita ini tentang pelatih Prancis, Didier Deschamps bahwa dirinya tidak peduli dengan taktik atau gaya bermain. Menurutnya, sikap mental, pengorbanan, dan kebersamaan di atas segalanya. Selain itu, organisasi permainan dan kedisiplinan dalam menjaga area pertahanan adalah dua hal yang utama.

Dalam berita ini terdapat lima karakteristik narasi, yaitu tanggungjawab pemain Prancis sebagai pengirim, pentingnya keseimbangan dalam permainan sebagai objek, skuad Prancis sebagai penerima, organisasi dan kedisiplinan timnas Prancis sebagai pendukung, dan Didier Deschamps sebagai subjek. Harian Kompas tidak menaruh hambatan pada berita ini, namun menjadikan keseimbangan dalam permainan sebagai objek berita agar skuad Prancis menerima hasil melawan Kroasia dengan mengikuti instruksi Didier Deschamps dengan organisasi dan kedisiplinan ketika di atas lapangan yang merupakan tanggung jawab bagi setiap pemain.

\section{Berita Kecepatan Jadi Andalan}

Berita ini tentang kehebatan lini tengah Prancis yang kuat dan lini depan yang cepat dengan pola 4-2-3-1, sukses mengalahkan Belgia di semi final. Duet Paul Pogba dan N'Golo Kante sebagai gelandang tengah semakin mengokohkan sektor tengah. Kemudian, duet penyerang sayap Antoine Griezmann dan Kylian Mbappe yang memiliki kecepatan menjadi andalan Prancis dalam urusan menyerang.

Dalam berita ini terdapat enam karakteristik narasi, yaitu Prancis bermain pragmatis sebagai pengirim, kecepatan timnas Prancis sebagai objek, Kroasia sebagai penerima, lini tengan dan depan timnas Prancis sebagai pendukung, pola permainan timnas Prancis sebagai subjek, dan bayangan kegagalan Prancis di final sebagai penghambat. Harian Kompas menjadikan bayangan kegagalan di final Piala Dunia 2006 dan final Piala Eropa 2016 sebagai hambatan Prancis sebelum memulai laga final melawan Kroasia. Untuk menghindari hambatan tersebut, Prancis dituntut untuk bermain pragmatis dengan mengandalkan pola permainan cepat antara lini tengah yang diisi Paul Pogba dan N'Golo Kante dan Antoine Griezmann di lini depan agar bisa menguasai pertandingan sejak menit pertama.

\section{Berita Les Bleus Di Puncak Dunia}

Berita ini menggambarkan keberhasilan Prancis menjuarai Piala Dunia usai mengalahkan Kroasia di final dengan skor 4-2. Ini merupakan gelar kedua Prancis setelah sukses juara di tahun 1998 saat menjadi tuan rumah, sekaligus menjadikan Didier Deschamps sebagai orang ketiga setelah Mario Zagallo dan Franz Beckenbauer yang mengangkat trofi Piala Dunia sebagai pemain dan pelatih.

Dalam berita ini terdapat lima karakteristik narasi, yaitu Didier Deschamps sebagai pengirim, euforia juara Piala Dunia 2018 sebagai objek, warga Prancis sebagai penerima, supporter Prancis sebagai pendukung, dan skuad timnas Prancis sebagai subjek. Harian Kompas tidak menempatkan hambatan pada berita ini, namun lebih mengarah pada objek, yaitu euforia Prancis yang mampu keluar sebagai juara Piala Dunia 2018 yang kedua kalinya sepanjang sejarah. Hal ini tak lepas dari peran Didier Deschamps sebagai pemain dan pelatih yang mampu juara Piala Dunia, serta pendukung Prancis yang hadir langsung di Luzhniki Stadium, Moskwa. Ini juga menjadi penantian panjang warga Prancis atas kerja keras skuad Prancis sepanjang Piala Dunia 2018.

\section{Berita Skuad Prancis Disambut Parade Kemenangan}

Berita ini tentang penyambutan pesta dan parade kemenangan yang akan dilaksanakan di pusat kota Paris dan merambah ke seluruh kota yang diramaikan oleh Presiden dan seluruh warga Prancis. Namun aksi 
kerusuhan dan vandalisme menodai parade ini meskipun polisi berhasil meredam aksi tersebut. Kemenangan ini juga sebagai wadah pemersatu unsur dan moral negara Prancis.

Dalam berita ini terdapat enam karakteristik narasi, yaitu skuad Prancis sebagai pengirim, Prancis juara Piala Dunia 2018 sebagai objek, Presiden dan Menteri Olahraga Prancis sebagai penerima, Warga Prancis sebagai pendukung, Parade kemenangan di pusar kota Paris sebagai subjek, dan kerusuhan di Champs-Elysees, Paris sebagai penghambat. Harian Kompas menempatkan kerusuhan dan aksi vandalism serta penjarahan di Champs-Elysees, Paris sebagai penghambat meskipun kepolisian setempat dengan cepat meredam aksi-aksi tersebut yang mengganggu parade kemenangan Prancis. Namun parade kemenangan Prancis di Piala Dunia 2018 tetap berlangsung meriah yang dirayakan oleh seluruh warga Prancis, serta mendapatkan sambutan hangat dari Presiden dan Menteri Olahraga Prancis. Berita Les Bleus Juara Tanpa Perlu Jenius

Berita ini tentang generasi emas Prancis hingga puluhan tahun mendatang karena mampu juara Piala Dunia 2018 tanpa pemain jenius dan kreatif. Hal ini berbeda ketika Prancis juara Piala Dunia 1998, di mana skuad tersebut ada Michael Platini dan Zinedine Zidane.

Dalam berita ini terdapat lima karakteristik narasi, yaitu pemain Prancis sebagai pengirim, era kejayaan Prancis sebagai objek, Trofi Piala Dunia sebagai penerima, Didier Deschamps sebagai pendukung, dan timnas Prancis sebagai subjek. Harian Kompas tidak menempatkan penghambat dalam berita ini, namun berfokus pada objek berita, yaitu era kejayaan Prancis yang sangat berbeda ketika juara Piala Dunia 1998 dengan Piala Dunia 2018, yang diisi oleh para pemain muda yang mampu tampil mengesankan selama Piala Dunia 2018, serta tak lepas dari peran pelatih Didier Deschamps yang mampu memotivasi para pemainnya dengan mental juara.
Berdasarkan hasil penelitian dari kedelapan berita tentang Prancis sebagai juara Piala Dunia 2018, peneliti telah menganalisis bahwa harian Kompas secara objektif dalam memberitakan setiap peristiwa. Hal ini karena setiap pemberitaan yang berkaitan dengan sepakbola sesuai fakta di atas lapangan, serta pemberitaannya secara mendalam dan menyeluruh. Dengan demikian, harian Kompas telah memberikan sesuatu yang lebih dari media online kepada pembaca.

Gaya tulisan yang ditunjukkan harian Kompas dalam pemberitaan Prancis sebagai juara Piala Dunia 2018 ini cukup detail, karena produk jurnalistik secara deskripsi sangat penting dalam pemberitaan olahraga, khususnya sepakbola dalam ajang Piala Dunia kepada pembaca. Selain itu, wartawan harian Kompas juga memperhatikan diksi yang tepat, bagian awal, tengah, dan akhir cerita agar memiliki keunggulan dalam menulis berita olahraga, dan juga harus mempunyai banyak referensi karena sangat penting sekali dan berkaitan dengan gaya tulisan. Menulis olahraga harus memberikan sesuatu yang lebih kepada pembaca, dan juga kualitas tulisan lebih diutamakan agar pembaca puas. Sebagai narasi memori kolektif, penulis olahragamemposisikansebagaitempatpemulihan kisah-kisah yang diceritakan kembali tentang ruang menghidupkan pemahaman. Jurnalisme olahraga memiliki lisensi untuk terlibat dalam menghibur audiens, karena melaporkan berita sebagai objek hiburan (Serazio, 2010: 156-160).

Berdasarkan analisa karakter yang dilakukan oleh peneliti ditemukan beberapa karakter dalam narasi Adu Taktik di Jumpa Pertama, karakter pertama dalam berita ini menggambarkan Didier Deschamps yang berkorban tanpa kompromi untuk kepentingan tim dan menjaga asa Les Bleus untuk menjuarai Piala Dunia 2018, dengan menjalankan skenario berdasarkan strategi dan taktik untuk melaju ke final. Karakter kedua dalam berita yang berjudul Ancaman Taji Si Ayam Jantan adalah tentang timnas Prancis yang diibaratkan 
seperti Ayam Jantan yang memiliki kemampuan menyerang dan bertahan dengan sama baiknya untuk mengalahkan lawan-lawannya. Karakter ketiga dari berita Les Blues Melawan Besar Kepala adalah kebersamaan tim, menekankan kolektivitas ketimbang kekuatan individual dalam meraih gelar juara, merupakan aspek yang sangat penting. Karakter keempat dari berita Semua untuk Satu, Satu untuk Trofiadalah penekanan tentang mental, pengorbanan, dan kebersamaan di atas segalanya bagi skuad Prancis, dengan tanggungjawab penuh saat pertandingan. Pada karakter kelima dari berita Kecepatan Jadi Andalan, memperlihatkan bahwa timnas Prancis memiliki kekuatan lini tengah dan kecepatan lini depan yang menjadikan karakter bermain Les Bleus secara pragmatis, baik dalam bertahan maupun menyerang. Karakter keenam dari berita Les Blues di Puncak Dunia menunjukkan timnas Prancis dengan gaya bermain yang biasa-biasa saja mampu menunjukkan sebagai tim terbaik dan memperoleh gelar Piala Dunia. Karakter ketujuh dari berita Skuad Prancis Disambut Parade Kemenangan adalah semangat nasionalisme yang tinggi ditunjukkan warga Prancis dalam menyambut kembalinya skuad timnas Prancis di Paris setelah meraih gelar juara dunia yang kedua kali. Karakter kedelapan dari berita Les Blues Juara Tanpa Perlu Genius adalah skuad Prancis bermain tanpa pemain bintang yang diisi oleh pemainpemain muda berbakat, mampu menampilkan performa terbaiknya. Kebersamaan tim yang menjadikan karakter Prancis kuat sehingga mampu keluar sebagai juara.

Peneliti mendapatkan temuan di lapangan bahwa harian Kompas memiliki narasi yang mudah dipahami dengan karakteristik narasi yang umum. Artinya, harian Kompas sangat memberikan kenyamanan dan wawasan yang luas dengan membangun cerita yang efektif serta menghibur pembaca melalui kisahkisah yang menarik. Hal ini berkaitan dengan teori naratif, karena menurut Walter Fisher, manusia lebih dapat terbujuk oleh sebuah cerita yang bagus dibandingkan oleh sebuah argument yang baik (Sobur, 2014: 237).

Dalam menarasikan Piala Dunia 2018, peneliti menilai harian Kompas lebih mengarah pada analisa dan sesuatu yang tidak banyak diketahui sehingga pengetahuan pembaca terhadap gelaran sepakbola menjadi meningkat, meskipun memberikan informasi pra dan pasca pertandingan secara lengkap. Karakter narasi harian Kompas tentang Prancis sebagai juara Piala Dunia 2018 adalah narasi deskriptif, bukan narasi sensasi. Penulisan narasi deskriptif memberikan gambaran, terutama melalui detail-detail yang konkret seperti karakter, suasana, atau peristiwa (Ishwara, 2011: 171).

Sepanjang menarasikan Prancis sebagai juara Piala Dunia 2018, harian Kompas menggambarkan karakter, suasana, dan peristiwa dengan detail yang konkrit. Artinya, bagian dari karakteristik narasi ataupun karakter pemain yang dinarasikan, mampu ditunjukkan dengan lengkap. Selain itu, penggambaran suasana maupun peristiwa saat Prancis juara Piala Dunia 2018 oleh harian Kompas dengan detail yang konkrit. Harian Kompas lebih menempatkan Prancis sebagai juara Piala Dunia 2018 dengan karakter tim yang kuat dan kompak dalam setiap narasinya.

\section{Simpulan}

Penelitian ini menyimpulkan bahwa harian Kompas memiliki narasi yang mudah dipahami dengan karakteristik narasi yang umum, karena Kompas sangat memberikan kenyamanan dan wawasan yang luas dengan membangun cerita yang efektif serta menghibur pembaca melalui kisah-kisah yang menarik. Berdasarkan analisa karakter yang dilakukan oleh peneliti ditemukan beberapa karakter dalam narasi Adu Taktik di Jumpa Pertama, karakter pertama dalam berita ini menggambarkan Didier Deschamps yang berkorban tanpa kompromi untuk kepentingan 
tim dan menjaga asa Les Bleus untuk menjuarai Piala Dunia 2018, dengan menjalankan skenario berdasarkan strategi dak taktik untuk melaju ke final. Karakter kedua dalam berita yang berjudul Ancaman Taji Si Ayam Jantan adalah tentang timnas Prancis yang diibaratkan seperti Ayam Jantan yang memiliki kemampuan menyerang dan bertahan dengan sama baiknya untuk mengalahkan lawan-lawannya. Karakter ketiga dari berita Les Blues Melawan Besar Kepala adalah kebersamaan tim, menekankan kolektivitas ketimbang kekuatan individual dalam meraih gelar juara, merupakan aspek yang sangat penting. Karakter keempat dari berita Semua untuk Satu, Satu untuk Trofi adalah penekanan tentang mental, pengorbanan, dan kebersamaan di atas segalanya bagi skuad Prancis, dengan tanggungjawab penuh saat pertandingan. Pada karakter kelima dari berita Kecepatan Jadi Andalan, memperlihatkan bahwa timnas Prancis memiliki kekuatan lini tengah dan kecepatan lini depan yang menjadikan karakter bermain Les Bleus secara pragmatis, baik dalam bertahan maupun menyerang. Karakter keenam dari berita Les Blues di Puncak Dunia menunjukkan timnas Prancis dengan gaya bermain yang biasa-biasa saja mampu menunjukkan sebagai tim terbaik dan memperoleh gelar Piala Dunia. Karakter ketujuh dari berita Skuad Prancis Disambut Parade Kemenangan adalah semangat nasionalisme yang tinggi ditunjukkan warga Prancis dalam menyambut kembalinya skuad timnas Prancis di Paris setelah meraih gelar juara dunia yang kedua kali. Karakter kedelapan dari berita Les Blues Juara Tanpa Perlu Genius adalah skuad Prancis bermain tanpa pemain bintang yang diisi oleh pemain-pemain muda berbakat, mampu menampilkan performa terbaiknya. Kebersamaan tim yang menjadikan karakter Prancis kuat sehingga mampu keluar sebagai juara. Kontribusi penelitian ini berupa rekomendasi kebijakan kepada media pemberitaan lain agar menuliskan berita narasi yang mudah dipahami dengan karakteristik narasi yang umum bagi pembaca.

\section{Daftar Pustaka}

Eriyanto. (2013). Analisis Naratif: DasarDasar dan Penerapannya dalam Analisis Teks Berita Media. Jakarta: Kencana Prenada Media Group. https:/www.republika.co.id/berita/piala-dunia/ serba-serbi-piala-dunia-2018/18/06/23/ par7sf257-ini-jumlah-uang-yangdihabiskan-fan-cina-di-piala-dunia-2018

ht t ps://bola.kom pas.com / read/2018/07/18/11320078/datastatistik-mengapa-piala-dunia2018 -1ayak-untuk-dikenang http://www.pikiran-rakyat.com/olahraga/2018/06/07/piala-dunia$2018-\mathrm{dalam}-\mathrm{angka}-425492$ https://sport.detik.com/sepakbola/ berita/4117268/7-angka-menarikdari-final-piala-dunia-2018 https://www.fifa.com/worldcup/news/ more-than-half-the-world-watchedrecord-breaking-2018-world-cup Ishwara, Luwi. (2011). Jurnalisme Dasar: Seri JurnalistikKompas. Jakarta:BukuKompas. Junaedi, Fajar. (2014). Merayakan Sepakbola: Fans, Identitas, dan Media edisi 1. Yogyakarta: Fandom. Moleong, Lexy J. (2010). Metode Penelitian Kualitatif. Bandung: PT Remaja Rosdakarya. Serazio, Michael. (2010). When the Sportswriters Go Marching. Sports Journalism, Collective Trauma, and Memory Methapors, 27(2), 156-160. Siswanto, Wahyudi. (2008). Pengantar Teori Sastra. Jakarta: Grasindo. Sobur, Alex. (2013). Filsafat Komunikasi:

Tradisi dan Metode Fenomenologi. Bandung: PT Remaja Rosdakarya. Sobur, Alex. (2014). Komunikasi Naratif. Bandung: PT Remaja Rosdakarya. Stoke, Jane.(2007). Howto Do Media and Cultural Studies. Panduan untuk Melaksanakan Penelitian dalam Kajian Media dan 
Budaya. Diterjemahkan oleh Santi Indra Astuti. Yogyakarta: Bentang Budaya Pustaka. Sugiyono. (2016). Metode Penelitian Kuantitatif, Kualitatif, dan R\&D. Bandung: Alfabeta. Sukendro, Suryo. (2014). Ensiklopedi

Catatan Emas Piala Dunia Sepanjang Masa. Yogyakarta: Ar-Ruzz Media. Suryawati, Indah. (2014). Jurnalistik Suatu Pengantar: Teori dan Praktik. Bogor: Ghalia Indonesia.
Sutopo. (2002). Metodologi Penelitian Kualitatif: Dasar Teori dan Terapannya Dalam Penelitian. Surakarta: Sebelas Maret University Press. Tamburaka, Apriadi. (2013). Agenda Setting Media Massa. Jakarta: PT Raja Grafindo Persada. Vegas, XavierRamonandTorrijos,JoseLuisRojas. (2017). Mapping Media Accountability Instruments. Sports Journalism, 26(2). 